\title{
Classical Biological Control of Tropical Soda Apple with Gratiana boliviana ${ }^{1}$
}

\author{
R. Diaz, J. Medal, K. Hibbard, A. Roda, A. Fox, S. Hight, P. Stansly, B. Sellers, J. Cuda and W. A. \\ Overholt ${ }^{2}$
}

The purpose of this article is to provide a summary of the major steps of the successful biological control program against tropical soda apple in Florida. The article covers the importance of the weed, identification and biology of the biological control agent, rearing and release efforts, establishment and impact, and, finally, our efforts to communicate the outcomes of the program to stakeholders.

\section{Introduction}

Tropical soda apple, Solanum viarum Dunal (Solanaceae), is a prickly shrub native to South America. First reported in Glades Co., Florida in 1988, tropical soda apple later spread to Georgia, Alabama, Louisiana, Texas, Mississippi, Tennessee, North Carolina, and South Carolina. It is a major problem in pastures and conservation areas. Negative impacts of tropical soda apple include reduction of cattle stocking rates, competition with native plants, and the costs associated with its control (application of herbicides and mowing). Additionally, dense thickets of the weed may disrupt the movement of wildlife.

Field surveys in South America for potential biological control agents of tropical soda apple were initiated in 1994 by researchers from the University of Florida in collaboration with scientists from Brazil and Argentina. South American insects identified as potential biological control agents of tropical soda apple included the defoliating leaf beetles, Gratiana boliviana Spaeth, Gratiana graminea Klug,

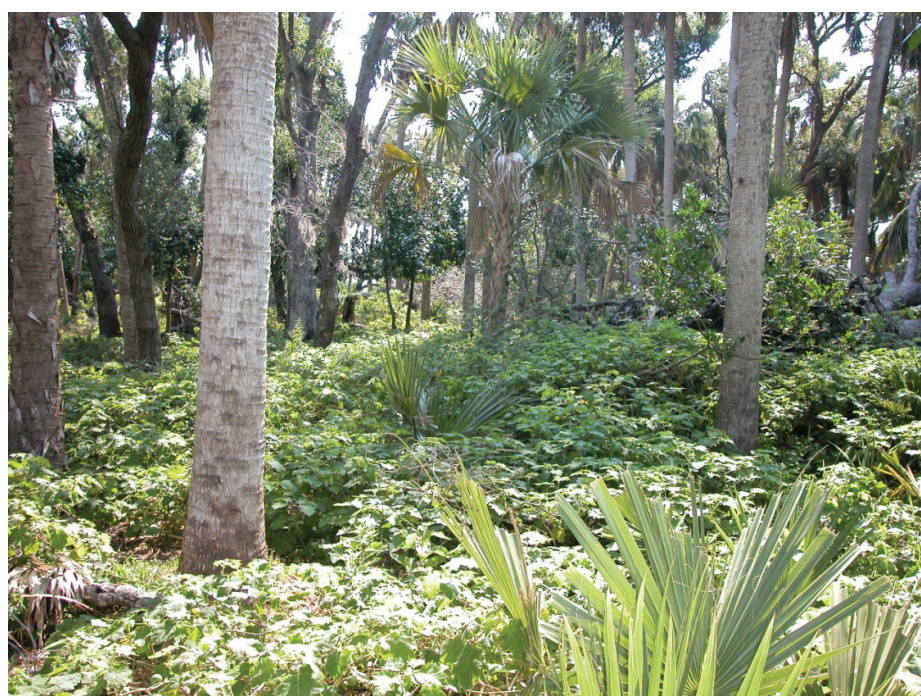

Figure 1. Infestation of tropical soda apple in St. Lucie Co., Florida. April 2006.

Credit: William A. Overholt, University of Florida

Metriona elatior Klug (Chrysomelidae), and the flower bud weevil, Anthonomus tenebrosus Boheman (Curculionidae).

Host specificity tests conducted under laboratory, greenhouse, and field conditions revealed that the tropical soda apple leaf beetle, G. boliviana, completed development only on tropical soda apple. Based on these findings, the USDAAPHIS-PPQ approved the field release of G. boliviana in the United States in 2002. The initial release was conducted in a pasture in Polk County, Florida, in May 2003. A multi-agency program supported the rearing, distribution,

1. This document is ENY865, one of a series of the Entomology and Nematology Department, Florida Cooperative Extension Service, Institute of Food and Agricultural Sciences, University of Florida. Original publication date November 2012. Visit the EDIS website at http://edis.ifas.ufl.edu.

2. R. Diaz , J. Medal, W. Overholt, P. Stansly, B. Sellers, and J. Cuda, Institute of Food and Agricultural Sciences, University of Florida; A. Roda, USDA-APHIS; K. Hibbard, A. Fox, FDACS-DPI; S. Hight, USDA-ARS. 
and release of more than 250,000 beetles across Florida from 2003 to 2011. Gratiana boliviana was also released in Texas, Alabama, and Georgia, but establishment has not been confirmed.

\section{Biology and Ecology of}

Females lay eggs individually on young leaves of tropical soda apple. Larvae hatch in 5-6 days and feed aggressively on the leaves. There are five instars, and after 16-18 days, mature larvae molt to the pupal stage. Pupae are found on the underside of leaves and this stage lasts for 6-7 days. Therefore, the total developmental time from egg to adult is about $29-31$ days at $25^{\circ} \mathrm{C}\left(77^{\circ} \mathrm{F}\right)$ (Fig. 2). Adults disperse by flying or walking especially during the warmest time of the day.

In Florida, Gratiana boliviana actively feeds and reproduces from March/April until October/November, and during these months can complete 7-8 generations. From December to early March, adults are in a reproductive diapause (resting stage), which allows them to survive periods of cold temperature and scarcity of food. Gratiana boliviana adults are difficult to locate during the winter because they hide in leaf litter beneath plants. Natural enemies of eggs, larvae, and pupae of G. boliviana include predators, parasitoids, and diseases.
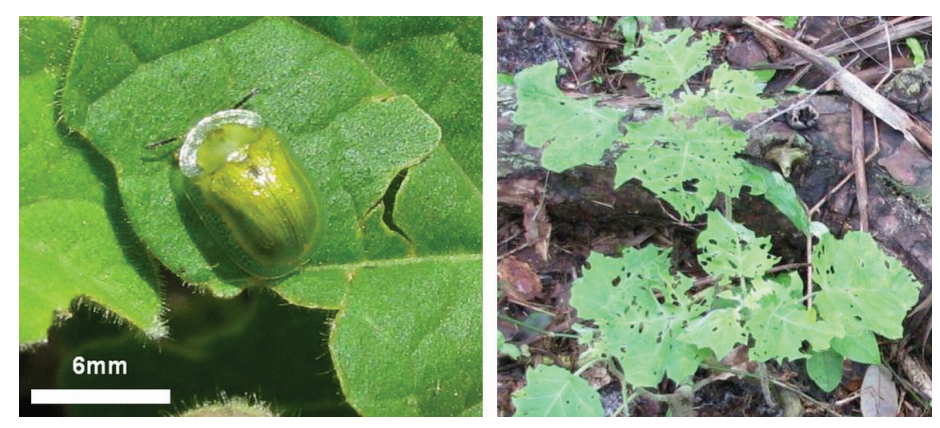

Figure 2. Gratiana boliviana adult and feeding damage; note shothole type damage on the leaves.

Credit: Rodrigo Diaz, University of Florida

\section{Rearing}

Gratiana boliviana was reared by the University of Florida, the Florida Department of Agriculture and Consumer Services, and the United States Department of Agriculture at locations in north, central, and south Florida (Fig. 3). Containers with beetles for field release were handdelivered to ranchers and other land managers, or shipped overnight in coolers. Upon arrival at release sites, groups of 10 to 20 adult beetles were manually transferred to naturally growing tropical soda apple plants.

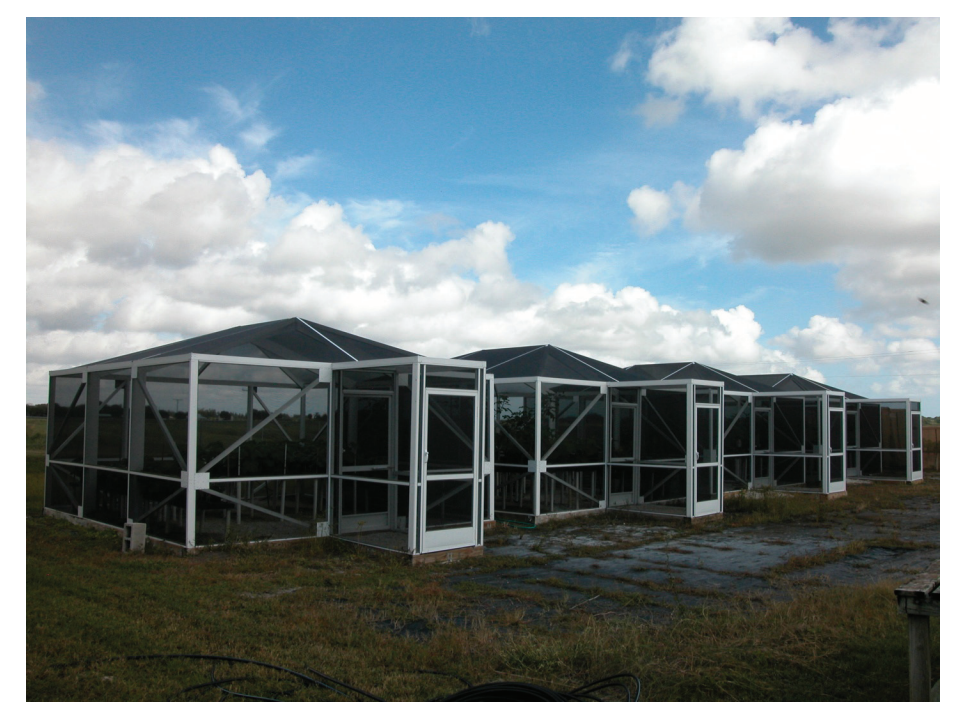

Figure 3. Screenhouses used for propagation of tropical soda apple and mass rearing of Gratiana boliviana in Fort Pierce.

Credit: Rodrigo Diaz, University of Florida

\section{Field Releases of}

A total of 250,723 G. boliviana adults were released in Florida from May 2003 to November 2011, with an average of 25,000 beetles released per year. Releases were made mostly in the central and southwestern part of the state from 2003 to 2007. In 2008, releases were expanded to include Miami-Dade and Broward Counties in the south, and Alachua, Bradford, and Union Counties in the northern peninsula. From 2009 to 2011, releases targeted a few sites in north Florida. By the end of the program, releases had been made throughout the state, with the majority in central Florida.

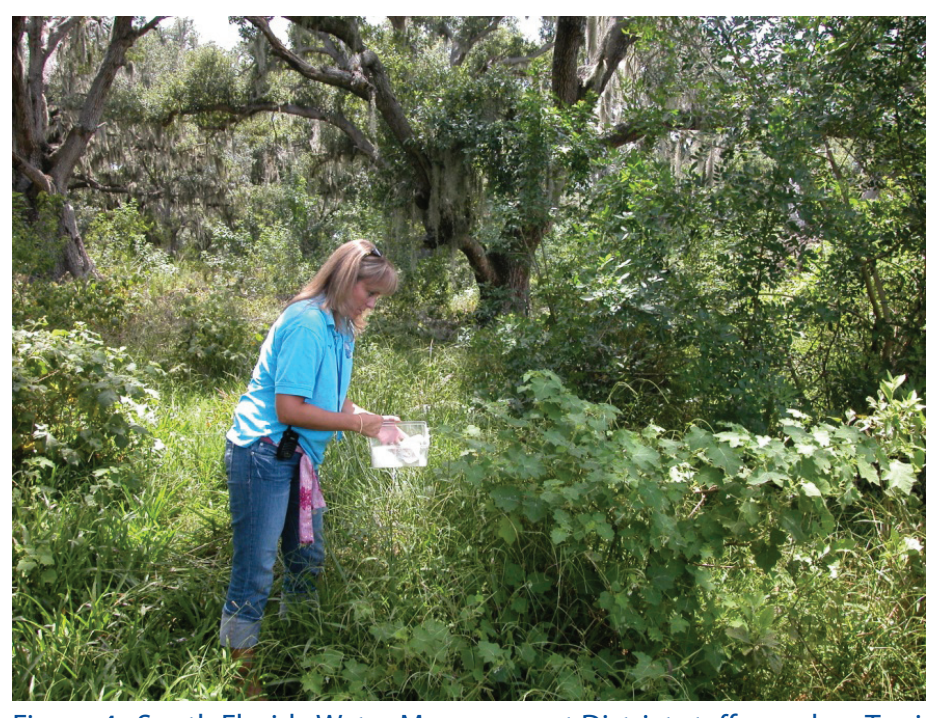

Figure 4. South Florida Water Management District staff member, Terri Torrens, releasing Gratiana boliviana adults on a tropical soda apple plant.

Credit: William A. Overholt, University of Florida 
Field releases of $G$. boliviana were a coordinated effort that included personnel from rearing facilities, scientists, and owners or managers of release sites. Releases were made by property owners, federal employees, and state employees (Fig. 4).

\section{Establishment of}

The establishment of G. boliviana was evaluated during field surveys across the state in 2008, 2009, and 2010, which were conducted during the summer months when beetles are most abundant. In 2008, G. boliviana was found at the majority of locations in 20 counties south of Wildwood in Sumter Co., but absent farther north and in far south Florida. Based on these results, efforts in 2009 were shifted towards releases in north and south Florida. The beetle became well established in Miami-Dade and Broward Counties, but not at locations in north Florida (Fig. 5). Reasons for the poor performance of the beetle in north Florida are not known, but may be due to high winter mortality.

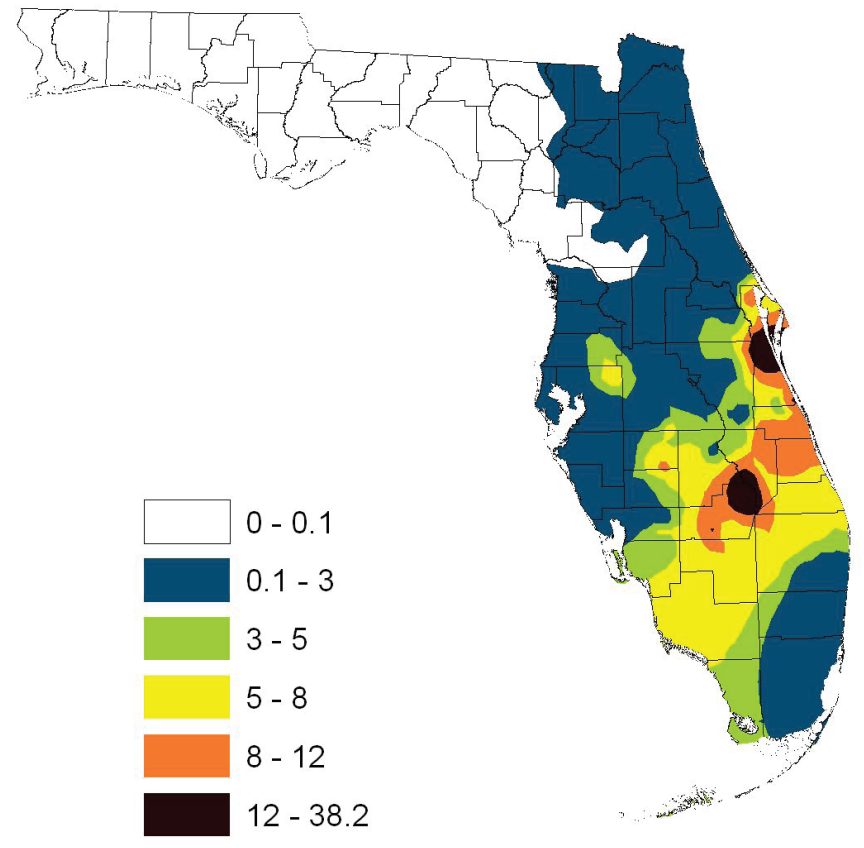

Figure 5. Density of Gratiana boliviana per plant during 2008 and 2010 in Florida.

Credit: Rodrigo Diaz, University of Florida

\section{Impact of}

Feeding damage by larvae and adults of G. boliviana is characterized by a distinctive "shotgun" hole pattern on leaves (Fig. 2) that is apparent from April to November. This damage not only reduces the photosynthetic area of the leaves, but also creates wounds that may facilitate attack by plant diseases. These cumulative stresses hinder the growth and reproduction of tropical soda apple. By reducing the competitive ability of the weed, G. boliviana indirectly facilitates the recovery of pasture grasses and native vegetation (Fig. 6).

Studies in central Florida pastures showed that G. boliviana can drastically reduce the density of tropical soda apple in less than one year after release, although it may take longer at some locations. Gratiana boliviana will not eliminate the weed from an infested area, but it will reduce the density of tropical soda apple to a more tolerable level. In some cases, biological control may need to be supplemented with herbicides and mowing, especially during the winter months when beetles are not active, and in north Florida where the impact of the beetle is low.

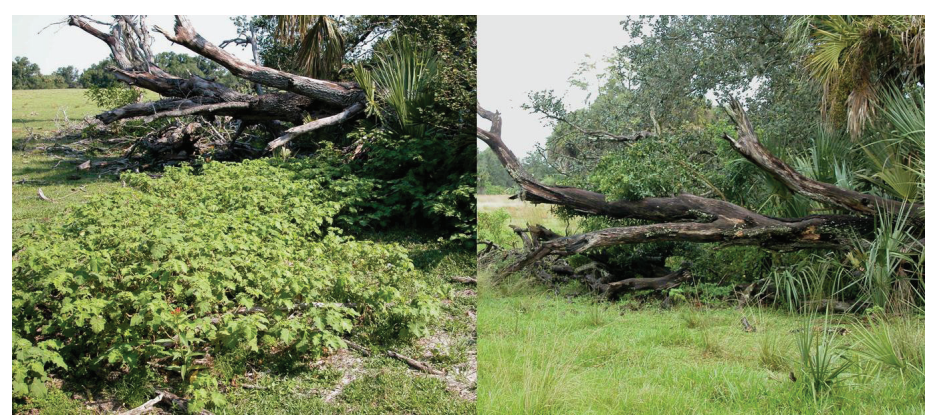

Figure 6. Pasture before and after the release of Gratiana boliviana, St. Lucie Co., Florida.

Credit: William A. Overholt, University of Florida

\section{Technology Transfer}

Major goals of the program were to inform the public about biological control and to promote the use of G. boliviana as a management tool against tropical soda apple. Several types of materials and methods were used to communicate with stakeholders. Demonstrations during field days allowed direct two-way communication between scientists and ranchers; websites served as a major depository of pictures, factsheets and videos; and the distribution of extension publications, particularly in the trade journal of the Florida Cattlemen's Association, informed stakeholders of the program and its progress. Toward the end of the program, a how-to manual containing information about the recognition, rearing, release, and impact of $G$. boliviana was freely distributed to thousands of ranchers across central and south Florida. In addition, YouTube videos were produced to deliver information to a broader audience about the identification of the plant, recognition of beetle damage, and a rancher's perspective on beetle impact (Plant recognition: http://www.youtube.com/ watch?v=uBjeS_yeeBk; Using Gratiana boliviana: http:// www.youtube.com/watch?v=MSFUMQaxL4k). Through these Extension efforts, the majority of Florida ranchers became aware of the biological control effort. 


\section{Lessons Learned}

The successful biological control of tropical soda apple in Florida is attributed in part to the collaborative efforts of property owners, extension agents, government employees, and scientists working together. This partnership facilitated the widespread distribution of G. boliviana in Florida, helped to raise public awareness about the program, and allowed constant feedback from stakeholders. Biannual meetings of scientists involved in the program helped to coordinate regional decisions and future management actions. An online database served as a repository of information for reporting release efforts to funding agencies and other stakeholders. Understanding the distribution of the biological control agent across Florida allowed us to effectively target our program efforts. Finally, the use of several delivery methods was critical during technology transfer and can serve as a model for other invasive plant programs.

Financial support for this project was provided by the United States Department of Agriculture, Animal Plant Health Inspection Service (USDA-APHIS) and the Florida Department of Agriculture and Consumer Services, Division of Plant Industry (FDACS-DPI). 